AGRICULTURE AND BIOLOGY JOURNAL OF NORTH AMERICA

ISSN Print: 2151-7517, ISSN Online: 2151-7525, doi:10.5251/abjna.2013.4.4.393.397

C 2013, ScienceHuß, http://www.scihub.org/ABJNA

\title{
Preweaning litter growth and weaning characteristics among inbred and cross bred native by exotic piglet genotypes
}

\author{
Nwakpu, P.E \\ Department of Animal Science, Ebonyi State University, Abakaliki, Nigeria. \\ ABSTRACT
}

Inbred strains generated from native and exotic pigs were compared for a range of pre-weaning and weaning letter performance traits. Animals were intensity reared and at 9 months of age, the inbred genotypes from each strain or breed were reciprocally mated to each other to generate $F_{1}$ cross bred genotypes. Results of the study showed that the Preweaning and weaning litter performances were better in the cross bred groups than in the inbred parents and this improvement could be ascribed to the dominant genes from the exotic parents. Significant $(P<0.05)$ difference was obtained in the Perweaning and weaning birth weight, mortality rate, litter weight, litter growth rate, and litter weaning characteristics like litter size at weaning, survival rate to weaning, litter weight gain at weaning, litter mates weight difference at weaning and weaning sex ratio respectively. The superior performance of crossbred genotypes over the inbred were attributed to maternal, age and body weight of dam rather than genetic effects. The generally low reproductive performance of the present stock of pigs suggests the need to upgrade them by cross-mating selected native pigs with new imports.

Keywords: Preweaning, Litter, Genotypes, Native, Exotic Inbred and Cross Bred.

\section{INTRODUCTION}

Litter production is an important aspect of commercial production in polytocous animals. It is an integral element in the short-term and long-term sustainability of commercial pig production.

One of the major reasons for introducing the improved breeds of pigs into Nigeria was to facilitate the upgrading of the productive qualities of the local genotypes of pigs by crossbreeding (Okwun et al., 1996). This is aimed at stemming the variations in meat output among the genetically improved exotic breeds and the largely improved indigenous types arising from differences in their growth rates mature body sizes and reproductive potentials (Adebambo and Onakade, 1983; Steinbach, 1985).

Whereas the genetically improved exotic breeds may be useful in upgrading the productive qualities of the indigenous types, the indigenous types which are reputed for their tolerance to trypanosomiasis may be useful in stabilizing the more vulnerable exotic breeds. The resultant crossbred tend to become more typonotolerant than their exotic parent exhibiting higher growth rates and attaining large mature body size than the pure indigenous types. These are desirable genetic attributes that can be harnessed during crossbreeding for improvement of litter size and reproductive traits among native pig genotypes before they become extinct. Our native pigs, according to Nwakpu and Ugwu, (2009), are noted to compare favorably in growth characteristics with their exotic counterparts and have the singular ability to transmit genes for early age at sexual maturity, good maternal ability, most probable producing ability (MPPA) and produced better heterosis in harsh conditions when crossed with the exotic breed.

Female reproductive traits have low to moderate heritability. The most heritable traits are those depending solely on the genotype of the female i.e. age at puberty, ovulation rate and weaning to estrus interval. Conversely, litter size, conception and survival rates and to a lesser extent, litter weight which result from complex interactions between sow, boar and embryo or piglet genotypes have low heritablity and are therefore difficult to improve through selection Ikeobi, 1998).

Pig producers have long known that crossbreeding is an effective means of improving reproduction performance. This improvement called heterosis or hybrid vigour, comes from an increase in heterozygosity, which, leads to better average genotype values at dominant loci. Litter traits are controlled by the genes of both piglets and sows and enhanced performance may come from crossed 
piglets (i.e. direct or individual heterosis effect) or crossed dams (i.e. sow or material heterosis effect) (Weiner, 1994).

Litter heterosis effects lead to slightly larger litter size at birth and to higher piglet survival and litter weights. The aim of the present work is to assess the preweaning and weaning reproductive performance among inbred and cross bred native by Exotic piglet genotypes.

\section{MATERIALS AND METHODS}

Experimental Animals : This comprised $F_{1}$ inbred strains generated from within mating of two exotic breeds of pigs (large white and landrace) and the Nigerian Native pig established and maintained at the Piggery Breeding Research Unit of Ebonyi State University, Abakaliki. Nigeria.

Mating Arrangement : At a months of age, inbred genotypes from each strain NxN, Lw $x$ Lw and LR $x$ LR representing native, large white and landrace inbreds, respectively were reciprocally mated to one another to generate $F_{1}$ crossbred populations.

Similarly, at 9 months of age, gilts from each crossbred group were backcrossed to the male parents to obtain four backcross progeny groups or genotypes. Artificial insemination was employed in the mating scheme to forestall the problems of size differences associated with hand mating.

Management Of The Animals :The animals were intensively reared in standard pens according to litter groups. Piglets were brooded and fed libitum for eight weeks with a commercial pig starter diet containing $22 \%$ crude protein and $2900 \mathrm{kcal} \mathrm{ME} / \mathrm{kg}$.

Water for drinking was provided ad libitum throughout the period. The animals were dewormed on routine basis and other therapeutic treatments provided as the need arose.

Data Collected And Analysis : Data were collected on weight at birth and at weaning, mortality at birth and at weaning, litter weight at birth and at weaning, litter growth rate up to weaning age, survival rate to weaning, litter weight gain at weaning litter mates' weight difference and sex ratio at weaning. Litter size was obtained by actual count of number of piglets in a litter. Mortality rate per litter at bi-weekly intervals was obtained as percent ratio of the number of piglets dead in each week to the total number of piglets in the same litter at the beginning of the next two weeks. Litter growth rate at bi-week to the litter weight in the preceding two weeks.

Survival rate to weaning was determined as the ration of mean litter size at birth to mean litter size at weaning (expressed in percentage). Litter weight gain at weaning were determined by deducting the piglet and litter birth weights from the piglet and litter weaning weights respectively. Difference between the heaviest and lightest members of the same litter at weaning gave litter mate weight difference at weaning. Date collected were subjected to analysis of variance in a completely randomized design (Steel and Torrie, 1980) with the various breeding groups as main source of variation. Duncan's new multiple range tests (Duncan, 1955) was used to separate the mean difference.

\section{RESULTS}

Mean weight form birth to eight weeks of race are indicated in table1. Mean birth weight $(\mathrm{kg})$ ranged between 0.90 to $1.40 \mathrm{~kg}$ at birth and 6.7 to $9.3 \mathrm{~kg}$ at weaning. It was higher in the in bred large white than other inbred genotypes and the difference was significantly $(P<0.05)$ different from the cross breds. Crossbred genotypes were born in larger numbers than the inbreds. Birth weight at weaning was significantly $(P<0.05)$ higher for the inbred large white than landrace or the native but was statistically $(P<0.05)$ higher for the inbred large white than landrace or the native but was statistically $(P>0.05)$ similar to the main cross bred genotypes of $(\mathrm{N} \times \mathrm{LW})$. Weight of the piglet more than doubled between 2 to 6 weeks of age and this indicated a period of highest growth rate among the piglet genotypes.

The proportion of piglets born dead varied from 2.2 to 6.63 at birth and 0.00 to 0.13 at weaning (table 2). It was slightly higher among crossbreds than the inbreds. preweaning mortality was significantly $(P<.0 .05)$ different at the second week only and nonsignificant $(P>0.05)$ at other ages.

Litter weight at birth ranged from 24.50 to $51.05 \mathrm{~kg}$ and 105.20 to $173.61 \mathrm{~kg}$ at weaning respectively. Litter weight at the various ages were significantly higher $(\mathrm{P}<0.05)$ in the cross breds than the inbreds. Litter growth rate was highest within the first two weeks of life (110-148) percent (Table 4). 
Table 1: Preweaning Birth and Weaning Weight $(\mathrm{kg})$ and Crossbred Piglet Genotypes Age (weeks)

\begin{tabular}{|l|l|l|l|l|l|l|}
\hline Inbreds & $\begin{array}{l}\text { No of } \\
\text { piglets }\end{array}$ & $\mathbf{0}$ & $\mathbf{2}$ & $\mathbf{4}$ & $\mathbf{6}$ & $\mathbf{8}$ \\
\hline $\mathrm{N} \times \mathrm{N}$ & 27 & $0.90 \pm 0.2^{\mathrm{d}}$ & $2.2 \pm 0.50^{\mathrm{c}}$ & $4.5 \pm 1.5^{\mathrm{c}}$ & $5.6 \pm 2.0^{\mathrm{c}}$ & $6.7 \pm 1.60^{\mathrm{d}}$ \\
\hline $\mathrm{LW} \times \mathrm{LW}$ & 32 & $1.40 \pm 0.5^{\mathrm{a}}$ & $3.2 \pm 1.0^{\mathrm{a}}$ & $6.2 \pm 2.0^{\mathrm{a}}$ & $7.3 \pm 1.2^{\mathrm{a}}$ & $9.3 \pm 1.20^{\mathrm{a}}$ \\
\hline $\mathrm{LR} \times \mathrm{LR}$ & 40 & $1.32 . \pm 0.5^{\mathrm{b}}$ & $2.8 \pm 1.5^{\mathrm{b}}$ & $5.9 \pm 1.7^{\mathrm{a}}$ & $6.9 \pm 1.3^{\mathrm{a}}$ & $8.5 \pm 1.50^{\mathrm{b}}$ \\
\hline $\begin{array}{l}\text { Crossbreds } \\
(\mathrm{N} \times \mathrm{N})\end{array}$ & 45 & $1.38 \pm 0.2^{\mathrm{b}}$ & $3.0 \pm 1.0^{\mathrm{a}}$ & $6.0 \pm 2.0^{\mathrm{a}}$ & $7.1 \pm 1.2^{\mathrm{a}}$ & $9.1 \pm 1.30^{\mathrm{a}}$ \\
\hline $\mathrm{LW} \times \mathrm{N}$ & 30 & $1.28 \pm 1.0^{\mathrm{c}}$ & $2.6 \pm 2.0^{\mathrm{b}}$ & $5.3 \pm 1.2^{\mathrm{b}}$ & $6.5 \pm 1.3^{\mathrm{b}}$ & $8.3 \pm 1.10^{\mathrm{b}}$ \\
\hline $\mathrm{N} \times \mathrm{LR}$ & 42 & $1.10 \pm 0.2^{\mathrm{d}}$ & $2.4 \pm 1.0^{\mathrm{c}}$ & $5.1 \pm 1.0^{\mathrm{b}}$ & $6.2 \pm 1.2^{\mathrm{b}}$ & $8.1 \pm 1.0^{\mathrm{b}}$ \\
\hline $\mathrm{LR} \times \mathrm{N}$ & 31 & $1.15 \pm 10^{\mathrm{c}}$ & $2.3 \pm 1.5^{\mathrm{c}}$ & $5.1 \pm 1.0^{\mathrm{b}}$ & $6.3 \pm 1.0^{\mathrm{b}}$ & $7.8 \pm 1.20^{\mathrm{c}}$ \\
\hline
\end{tabular}

a, b, c. d: Means at same age not followed by some superscript are different $(P<0.05)$.

$\mathrm{N} \times \mathrm{N}=$ Native boar $\times$ Native gilt

Lw $x$ Lw $=$ Large white boar $\times$ Large White gilt

$\mathrm{LR} \times \mathrm{LR}=$ Landrace boar $\times$ Landrace gilt

$\mathrm{N} \times \mathrm{LW}=$ Native boar $\times$ large white gilt (Reciprocal crossbred)

Lw $\times \mathrm{N}=$ Large white boar $\times$ Native gilt (Main cross bred)

$\mathrm{N} \times \mathrm{LR}=$ Native boar $\times$ Landrace gilt (Reciprocal Cross bred)

$\mathrm{LR} \times \mathrm{N}=$ Landrace boar $\times$ Native gilt (Main Cross Bred)

Table 2: $\quad$ Pre-Weaning Mortality Rate (\%) Per litter in inbred and crossbred piglet genotype. Age (weeks)

\begin{tabular}{|l|l|l|l|l|l|l|}
\hline Inbreds & $\begin{array}{l}\text { No of } \\
\text { piglets }\end{array}$ & 0 & 2 & 4 & 6 & 8 \\
\hline $\mathrm{N} \times \mathrm{N}$ & 27 & $2.5 \pm 0.10$ & $4.40 \pm 2.7^{\mathrm{c}}$ & $5.10 \pm 1.0$ & $0.00 \pm 0.0$ & $0.00 \pm 0.00$ \\
\hline $\mathrm{Lw} \times \mathrm{Lw}$ & 32 & $2.65 \pm 0.50$ & $17.2 \pm 1.0^{\mathrm{a}}$ & $3.10 \pm 2.5$ & $1.20 \pm 1.0$ & $0.00 \pm 0.00$ \\
\hline $\mathrm{LR} \times \mathrm{LR}$ & 40 & $3.76 \pm 1.50$ & $18.5 \pm 2.0^{\mathrm{a}}$ & $8.20 \pm 1.6$ & $3.35 \pm 0.2$ & $0.00 \pm 0.00$ \\
\hline $\begin{array}{l}\text { Crossbreds } \\
(\mathrm{N} \times \mathrm{Lw})\end{array}$ & 45 & $3.48 \pm 2.5$ & $20.50 \pm 1.0^{\mathrm{a}}$ & $9.50 \pm 2.0$ & $2.20 \pm 0.6$ & $1.3 \pm 2.50$ \\
\hline $\mathrm{Lw} \times \mathrm{N}$ & 30 & $2.8 \pm 2.0$ & $14.50 \pm 2.0^{\mathrm{b}}$ & $4.50 \pm 2.50$ & $3.30 \pm 1.0$ & $0.3 \pm 1.5$ \\
\hline $\mathrm{N} \times \mathrm{LR}$ & 42 & $6.63 \pm 10.50$ & $18.60 \pm 2.0^{\mathrm{a}}$ & $4.12 \pm 1.0$ & $2.40 \pm 0.50$ & $0.00 \pm 0.00$ \\
\hline $\mathrm{LR} \times \mathrm{N}$ & 31 & $2.2 \pm 1.50$ & $13.60 \pm 2.5^{\mathrm{b}}$ & $3.15 \pm 1.5$ & $4.2 \pm 0.6$ & $0.00 \pm 0.00$ \\
\hline
\end{tabular}

$\mathrm{a}, \mathrm{b}, \mathrm{c}$ : Means in the same column carrying different superscripts are different $(\mathrm{P}<0.05)$.

Table 3: $\quad$ Per- Weaning Litter Weight $(\mathrm{kg})$ Per litter in inbred and crossbred piglet genotype.

Age (weeks)

\begin{tabular}{|c|c|c|c|c|c|c|}
\hline Inbreds & No of piglets & 0 & 2 & 4 & 6 & 8 \\
\hline $\mathrm{N} \times \mathrm{N}$ & 27 & $\begin{array}{l}24.50^{\mathrm{a}} \\
\pm 0.50\end{array}$ & $\begin{array}{l}48.90^{\mathrm{a}} \\
\pm 1.51\end{array}$ & $\begin{array}{l}66.93^{\mathrm{a}} \\
\pm 2.43\end{array}$ & $\begin{array}{l}89.30^{\mathrm{a}} \\
\pm 3.10\end{array}$ & $\begin{array}{l}105.20^{\mathrm{a}} \\
\pm 3.72\end{array}$ \\
\hline$L w \times L w$ & 32 & $\begin{array}{l}36.40^{b} \\
\pm 0.20\end{array}$ & $\begin{array}{l}53.10^{b} \\
\pm 1.10\end{array}$ & $\begin{array}{l}73.41^{\mathrm{a}} \\
\pm 2.10\end{array}$ & $\begin{array}{l}98.38^{b} \\
\pm 4.10\end{array}$ & $\begin{array}{l}140.80^{b} \\
\pm 5.10\end{array}$ \\
\hline $\mathrm{LR} \times \mathrm{LR}$ & 40 & $\begin{array}{l}44.80^{c} \\
\pm 0.61\end{array}$ & $\begin{array}{l}76.30^{c} \\
\pm 2.05\end{array}$ & $\begin{array}{l}95.30^{b} \\
\pm 1.15\end{array}$ & $\begin{array}{l}133.20^{\mathrm{C}} \\
\pm 2.50\end{array}$ & $\begin{array}{l}161.20^{\mathrm{C}} \\
\pm 6.50\end{array}$ \\
\hline Crossbreds $(\mathrm{N} \times \mathrm{Lw})$ & 45 & $\begin{array}{l}51.05^{d} \\
\pm 0.72\end{array}$ & $\begin{array}{l}81.40^{d} \\
\pm 1.32\end{array}$ & $\begin{array}{l}121.16^{\mathrm{C}} \\
\pm 2.51\end{array}$ & $\begin{array}{l}143.25^{\mathrm{d}} \\
\pm 2.40\end{array}$ & $\begin{array}{l}173.61^{\mathrm{d}} \\
\pm 7.81\end{array}$ \\
\hline $\mathrm{Lw} \times \mathrm{N}$ & 30 & $\begin{array}{l}38.10^{b} \\
\pm 0.30\end{array}$ & $\begin{array}{l}50.40^{b} \\
\pm 0.30\end{array}$ & $\begin{array}{l}68.72^{\mathrm{a}} \\
\pm 1.71\end{array}$ & $\begin{array}{l}89.35^{\mathrm{a}} \\
\pm 2.62\end{array}$ & $\begin{array}{l}121.61^{\mathrm{a}} \\
\pm 4.85\end{array}$ \\
\hline $\mathrm{N} \times \mathrm{LR}$ & 42 & $\begin{array}{l}46.56^{\mathrm{C}} \\
\pm 0.32\end{array}$ & $\begin{array}{l}70.50^{C} \\
\pm 1.31\end{array}$ & $\begin{array}{l}101.53^{\mathrm{b}} \\
\pm 2.61\end{array}$ & $\begin{array}{l}141.15^{\mathrm{d}} \\
\pm 3.64\end{array}$ & $\begin{array}{l}138.53^{\mathrm{d}} \\
\pm 4.95\end{array}$ \\
\hline $\mathrm{LR} \times \mathrm{N}$ & 31 & $\begin{array}{l}36.40^{\circ} \\
\pm 0.43\end{array}$ & $\begin{array}{l}52.10^{\circ} \\
\pm 0.45\end{array}$ & $\begin{array}{l}71.21^{\mathrm{a}} \\
\pm 1.31\end{array}$ & $\begin{array}{l}98.61^{\mathrm{b}} \\
\pm 0.79\end{array}$ & $\begin{array}{l}138.53^{\circ} \\
\pm 6.70\end{array}$ \\
\hline
\end{tabular}

a, b, c: Means in the same column carrying different superscripts are significantly different $(\mathrm{P}<0.05)$. 
Table 4: Pre- Weaning Litter growth rate (\%) in inbred and crossbred piglet genotype. Age (weeks)

\begin{tabular}{|l|l|l|l|l|l|l|}
\hline Inbreds & No of Piglets & 0 & 2 & 4 & 6 & 8 \\
\hline $\mathrm{N} \times \mathrm{N}$ & 27 & $138 \pm 50^{\mathrm{c}}$ & $75 \pm 15^{\mathrm{a}}$ & $78 \pm 60^{\mathrm{a}}$ & $73 \pm 70^{\mathrm{a}}$ & $105 \pm 10^{\mathrm{b}}$ \\
\hline Lw $\times$ Lw & 32 & $121 \pm 20^{\mathrm{c}}$ & $86 \pm 25^{\mathrm{a}}$ & $89 \pm 20^{\mathrm{a}}$ & $85 \pm 40^{\mathrm{a}}$ & $115 \pm 20^{\mathrm{b}}$ \\
\hline LR $\times$ LR & 40 & $136 \pm 60^{\mathrm{c}}$ & $93 \pm 17^{\mathrm{a}}$ & $101 \pm 30^{\mathrm{a}}$ & $94 \pm 40^{\mathrm{a}}$ & $121 \pm 40^{\mathrm{b}}$ \\
\hline $\begin{array}{l}\text { Crossbreds } \\
\text { (N } \times \text { Lw) }\end{array}$ & 45 & $143 \pm 20^{\mathrm{c}}$ & $83 \pm 19^{\mathrm{a}}$ & $112 \pm 50^{\mathrm{b}}$ & $96 \pm 40^{\mathrm{a}}$ & $136 \pm 40^{\mathrm{c}}$ \\
\hline Lw $\times \mathrm{N}$ & 30 & $110 \pm 30^{\mathrm{c}}$ & $78 \pm 40^{\mathrm{a}}$ & $121 \pm 42^{\mathrm{c}}$ & $98 \pm 20^{\mathrm{b}}$ & $145 \pm 20^{\mathrm{a}}$ \\
\hline $\mathrm{N} \times$ LR & 42 & $148 \pm 65^{\mathrm{d}}$ & $87 \pm 26^{\mathrm{a}}$ & $100 \pm 25^{\mathrm{b}}$ & $87 \pm 35^{\mathrm{a}}$ & $132 \pm 20^{\mathrm{c}}$ \\
\hline LR $\times \mathrm{N}$ & 31 & $130 \pm 20^{\mathrm{b}}$ & $92 \pm 16^{\mathrm{a}}$ & $140 \pm 20^{\mathrm{c}}$ & $93 \pm 18^{\mathrm{a}}$ & $146 \pm 65^{\mathrm{c}}$ \\
\hline
\end{tabular}

$a, b, c$ : Means in the same column carrying different superscripts are significantly different $(\mathrm{P}<0.05)$.

Table 5: Litter Weaning Characteristics in inbred and Crossbred Piglet Genotype.

\begin{tabular}{|l|l|l|l|l|l|l|}
\hline Inbreds & $\begin{array}{l}\text { No } \\
\text { Piglets }\end{array}$ & of & SRW & LWGW & LMWD & WSR \\
\hline $\mathrm{N} \times \mathrm{N}$ & 22 & $6.5 \pm 1.65^{\mathrm{b}}$ & $82 \pm 21$ & $20.67 \pm 4.16^{\mathrm{b}}$ & $38 \pm 21^{\mathrm{a}}$ & $58 \pm 28$ \\
\hline Lw $\mathrm{Lw}$ & 28 & $8.9 \pm 1.51^{\mathrm{d}}$ & $86 \pm 20$ & $10.38 \pm 2.01^{\mathrm{a}}$ & $32 \pm 17^{\mathrm{a}}$ & $56 \pm 20$ \\
\hline LR $\times$ LR & 35 & $7.2 \pm 1.10^{\mathrm{c}}$ & $73 \pm 16$ & $19.50 \pm 4.35^{\mathrm{b}}$ & $59 \pm 18^{\mathrm{d}}$ & $51 \pm 15$ \\
\hline $\begin{array}{l}\text { Crossbreds (N } \\
\text { Lw) }\end{array}$ & 40 & $8.2 \pm 2.50^{\mathrm{d}}$ & $86 \pm 28$ & $21.50 \pm 5.16^{\mathrm{b}}$ & $68 \pm 21$ & $55 \pm 10$ \\
\hline Lw $\times \mathrm{N}$ & 28 & $7.3 \pm 1.16^{\mathrm{c}}$ & $78 \pm 15$ & $18.63 \pm 6.40^{\mathrm{b}}$ & $48 \pm 19^{\mathrm{b}}$ & $59 \pm 60$ \\
\hline $\mathrm{N} \times \mathrm{LR}$ & 38 & $6.5 \pm 1.70^{\mathrm{b}}$ & $81 \pm 19$ & $22.10 \pm 5.10^{\mathrm{b}}$ & $53 \pm 20^{\mathrm{c}}$ & $57 \pm 18$ \\
\hline LR $\times \mathrm{N}$ & 27 & $5.2 \pm 1.80^{\mathrm{a}}$ & $76 \pm 22$ & $18.90 \pm 1.63^{\mathrm{b}}$ & $61 \pm 16^{\mathrm{d}}$ & $60 \pm 10$ \\
\hline
\end{tabular}

a, b, c d: Means on the same column carrying different superscript are significantly different $(\mathrm{P}<0.05)$.

LSW $=$ Liter size t weaning

SRW $=$ survival rate to weaning

LWGW = Liter weight, gain at weaning

LMWD = Litter Mates Weight difference at weaning

WSR $=$ Weaning Sex Ratio

Rate of growth decreased with increase in the age of the piglets. Litter size at weaning, litter weight gain at weaning and survival rate to weaning were significantly $(P<0.05)$ higher in the crossbreds than in the inbred genotypes. Weaning sex ratio tended to be male biased (51-59\%) although, this estimates was associated with large standard deviations. The exotic crossbred genotypes were superior to their native counterparts, especially in the reciprocal crossbreds.

DISCUSSION: The significant differences observed among the inbred lines of each exotic strain in some of the traits categorized them as distinct groups which can contribute to the improvement of the native pig. The data obtained in the crossbred groups indicate that while sire influence affected. Litter characteristics at birth and at weaning, non-additive genetic effects were responsible for the inheritance of the traits in the other crossbred groups. (Gunset and Robinson, 1990).

Litter characteristics obtained in this report were within the range reported in south-west Nigeria by

Olomu and Oboh, (1995). The significant differences observed among the genotypes in some of the traits monitored, suggests that rearing factors, such as milking ability, litter size and mothering ability are perhaps as important as genetic effects (Luke Faly et al, 1984).

The highest mortality rate was recorded during the first 2-weeks of life. The first two weeks of life represents the most critical stage for the new born piglets. At this time, they are fragile, some blind and obligatory milk dependent.

Patridge et al (1981) observed that crushing, asphyxia chilling, starvation, injuries and diseases accounted for a large chunk of deaths among new born litters. However, the survival rate obtained in this work is similar to the report of Nguyen et al, (2001).

Results obtained in the present report indicated that new born piglets more than doubled their weights within the first two weeks of life and that the rate of growth declined with age. Manipulation of the lactating dam to secrete more milk through nutrition 
and hormone treatments may further enhance the growth and weaning weights of piglet.

The lower performance of crossbred piglets 9especially main crossbreds) compared with the exotic inbreds in this study may be due to maternal effect of differences in dam age and dam body weights. The crossbred piglets were mostly born by younger, inexperienced nulliparous dams. Ovulation potential, the first factor affecting prolificacy is said to increase, on the average, with dam size (lkeobi, 1998). Afifi et al., (1989) also submitted that maternal effect of body weight is important for litter size and weight of piglets. This is because, the larger and heavier the dam is, the more its uterine capacity and litter size. It is also possible that the higher survival rate of crossbred genotypes was due to their superior birth weight. Sandford (1989) had noted a considerable relationship between high birth weight and subsequent growth, development and ability of the young to thrive.

It can be noted that impressive levels of heteroses for litter size traits were observed in the crosses between the native and exotic pigs, which were more in some groups (especially the reciprocal crossbred groups) than in others. Earlier studies by Nwakpu and Omeje (2004), Nwakpu and ugwu (2009) had reported positive and significant heteroses in the reciprocal crossbred but not on the main crossbred. The researcher inferred that crossing the exotic boar with native sow would yield rapid improvement especially when the parents of the crossbred are confined. The $F_{1}$ crossbred groups differed in their heterotic performance on litter size traits, which was due to the nature and the degree of gene frequency differences between the parental lines, since heterosis is directly proportional to heterozygosity (Falconer 1989). The presence of these reciprocal cross differences will be useful in making decisions either to use the sire or dam of the superior strains in the improvement of litter size in pigs.

\section{REFERENCES}

Adebambo, O.A and A. D. Onakade (1983). Growth and carcass traits of crossbred boars of exotic and Nigerian indigenous pigs. J. Anim. Prod. Res. 3: 71-87.

Afifi, E. A., M. H Khalil and M. E Emara (1989). Effect of maternal performance on litter pre-weaning traits of doe rabbits. J. Anim. Breed. Genetics. 106:35-36.
Duncan, D. B (1955). Multiple range and multiple F- test. Biometrics, 11:1-42.

Falconer, D. S (1989). Introduction to quantitative genetics $2^{\text {nd }}$ ed. London. Inc. P. 564.

Gunsett, F. C. and Robinson, O. W (1990). Crossbreeding effects on reproduction, growth and carcass traits. In: Young L. D (ed). Genetics of swine. NC- 103 Publication. PP. 57-72.

Ikeobi, C.O.N (1998). Heterosis in Exotic breeds of pigs in a Nigerian Herd. Indian Journal of Animal Science 63 (11) $1110-1117$.

Lukefahr, S. D., W. D. Hoheiboken, P.R Cheeke and N. M Patton (1984). Genetic effects on maternal performance and litter pre- weaning and post- weaning traits in rabbits. Anim. Prod. 38:293.

Nwakpu, P. E and S. I Omeje (2004). Heterosis for body weight in Native by Exotic in bred pig crosses. Journ. Science, Agric. Food Techn. and Environ. 4:50-60.

Nwakpu, P.E and S. O.C Ugwu (2009). Heterosis for litter traits in Native by Exotic inbred pig crosses. Agroscience 8 (1): 31-37.

Nguyen, D.V., I. Salay; V. L Hoang and T. D. X. do (2001). Results of Vietnam - Hungary Scientific cooperation in Vietnam from 1998 to 2001 (August 2001 report).

Olomu, J.M and S. O. Ohoh (1995). Pig production in Nigeria: principles and practice. A jachem Publication, Nigeria. Pg 186.

Okwun, O. E., G. Igboeli, J. J. Ford, D.D Lunstra and L. Johnson (1996). Number and Function of sertoli cell, number and yield of Spermatogonia and daily sperm production in three breeds of boars. J. Repr. Fert. 107:137-149.

Patridge, G. G., S. Fotey and W. Corrigall (1981). Reproductive Performance of pure bred and crossbred commercial rabbits. Anim. Prod. 32: 325333.

Steel, R. G. D and J. H. Torrie (1980). Principles and Procedures of Statistics. Mc Graw hill, New York. Pg 108.

Steinbach, J. (1985). Impact of hot climate on feeding of farm Animals: Aspects of Pig Nutrition in tropical climates. $36^{\text {th }}$ Ann. Meeting of the European Assoc. for Anim. Prod. Held in Greece; $30^{\text {th }}$ September- $3^{\text {rd }}$ Oct., 1985.

Sandford, J. C (1986). The domestic rabbit. $4^{\text {th }}$ ed. Mac Kays and Patton, kent. 250pp.

Weiner, G. (1994). The Tropical Agriculturist. Animal Breeding Macmillan press Ltd. London. pp 208. 